\title{
Pediocin A, a bacteriocin produced by Pediococcus pentosaceus FBB61
}

\author{
Andrea Piva' and Denis R. Headon² \\ Author for correspondence: Andrea Piva. Tel: +39 51 792883. Fax: +3951 792869.
}

1 Istituto di Zootecnia e Nutrizione Animale, Facoltà di Medicina Veterinaria, Università di Bologna, 40064 Ozzano Emilia (BO), Italy

2 Department of Biochemistry, Cell and Molecular Biology Group, University College Galway, Ireland

\begin{abstract}
Pediocin A, a bacteriocin produced by Pediococcus pentosaceus FBB61, was purified and partially characterized. The purification was achieved by dialysis against PEG 20000, butanol extraction and electroendosmotic preparative electrophoresis. The protocol led to a 7843-fold increase in the specific activity, with $3.9 \%$ activity recovered. SDS-PAGE of pediocin A resulted in a single $80 \mathrm{kDa}$ protein band. The antimicrobial compound was sensitive to proteolytic enzymes and heat $\left(10 \mathrm{~min}\right.$ at $\left.100{ }^{\circ} \mathrm{C}\right)$. It exhibited inhibition against species of Lactobacillus, Lactococcus, Leuconostoc, Pediococcus, Staphylococcus, Enterococcus, Listeria and Clostridium.
\end{abstract}

Keywords: pediocin A, bacteriocin, Pediococcus pentosaceus, food microbiology

\section{INTRODUCTION}

An outstanding feature of lactic acid bacteria, accounting for their wide utilization in dairy, meat and vegetable fermentations, is their inhibitory activity against a variety of food-spoilage micro-organisms (Bhunia et al., 1988; Pucci et al., 1988; Spelhaug \& Harlander, 1989). Among antimicrobial substances produced by lactic acid bacteria, bacteriocins have gained increasing interest as possible natural food preservatives. Bacteriocins are heterogeneous in terms of spectra of activity, optimal conditions for activity, molecular masses, biochemical characteristics and sequence homologies. Nisin, a bacteriocin produced by certain strains of Lactococcus lactis subsp. lactis, was approved as a GRAS human food ingredient by the FDA in 1988 (Food and Drug Administration, 1988).

Pediococcal strains are used for meat and vegetable fermentations. Pediocin AcH and pediocin PA-1, produced by different strains of Pediococcus acidilactici were purified (Bhunia et al., 1988; Henderson et al., 1992), and later demonstrated to be identical (Motlagh et al., 1992). Pediocins have been successfully used to inhibit Listeria monocytogenes in several food systems (Pucci et al., 1988; Yousef et al., 1991). Pediococcus pentosaceus FBB61 was originally isolated in 1953 from a cucumber fermentation (Costilow et al., 1956). The inhibitory activity of this strain was observed by Etchells et al. (1964) in pure culture fermentations of cucumbers, and further investigated by Fleming et al. (1975). Rueckert (1979)

Abbreviations: $A U$, activity units; EPE, electroendosmotic preparative electrophoresis. characterized the chemical nature of the inhibitory material as proteinaceous and nondialysable across a semipermeable membrane, and its action as bactericidal. Daeschel \& Klaenhammer (1985) associated the production and immunity phenotype $\left(\mathrm{Bac}^{+} \mathrm{Imm}^{+}\right)$to a 13.6 MDa plasmid. Spelhaug \& Harlander (1989) demonstrated that $P$. pentosaceus FBB61 was inhibitory to several strains of $L$. monocytogenes, but had no effect against any Gram-negative bacteria tested.

No additional data are available about the characteristics of pediocin A, its genetic determinants, possible homologies with other bacteriocins and mode of action. This study deals with the purification and partial characterization of pediocin A, produced by $P$. pentosaceus FBB61, with a view to evaluating its possible utilization as a food preservative.

\section{METHODS}

Bacterial strains and media. P. pentosaceus FBB61 (ATCC 43200) and 'Lactococcus lactis subsp. diacetilactis' (L. lactis subsp. lactis) $\mathrm{CH} 001$, used as an indicator strain, were propagated at $30^{\circ} \mathrm{C}$ in M17 broth (Sambrook et al., 1989). The medium used for bacteriocin production was $\mathrm{M} 17+1 \%(\mathrm{w} / \mathrm{v})$ glucose. Agar media were prepared by adding $1.5 \%(\mathrm{w} / \mathrm{v})$ granulated agar to the broth media. Soft and overlay agars were prepared with $0.75 \%$ agar.

Bacteriocin production. $P$. pentosaceus FBB61 was grown in $\mathrm{M} 17+1 \%$ glucose at $30^{\circ} \mathrm{C}$ for $24 \mathrm{~h}$. The culture supernatant was then collected, adjusted to $\mathrm{pH} 6.5$, filtered through $0.22 \mu \mathrm{m}$ pore-size filters, concentrated to $0 \cdot 1$ volume by polyethylene glycol dialysis (Sigma, PEG 20000) and again filter-sterilized. This material was designated crude pediocin $A$ and was frozen at $-20{ }^{\circ} \mathrm{C}$ when not used immediately. 
Bacteriocin titration. Serial twofold dilutions of the crude extract and purified protein were made in sterile distilled water. From each dilution $30 \mu \mathrm{l}$ aliquots were delivered into wells in an M17 agar (1.5\%) plate previously seeded with $10 \mu$ of a fresh overnight culture (Lactococcus lactis subsp. lactis $\mathrm{CH} 001$ ) (approx. $10^{7}$ c.f.u.) and incubated at $30^{\circ} \mathrm{C}$. The sample titre was defined as the reciprocal of the highest dilution showing definite inhibition of the indicator lawn and was expressed in activity units (AU) $\mathrm{mi}^{-1}$.

Purification of pediocin A. (i) Butanol extraction. Crude pediocin A, prepared from M17 supernatant, was mixed with butanol (2:3 ratio). The mixture was vortexed for $30 \mathrm{~s}$ and left: for $30 \mathrm{~min}$. The butanol phase was removed and freeze-dried. All manipulations were at $0^{\circ} \mathrm{C}$. The powder was resuspended in ultrapure water in one-fifteenth of the original volume.

(ii) Non-denaturing gels and direct detection of antimicrobial activity. Non-denaturing polyacrylamide gels were prepared with a mixture of $15 \%(\mathrm{w} / \mathrm{v})$ acrylamide and $0.4 \%(\mathrm{w} / \mathrm{v})$ bisacrylamide, without SDS. Butanol extract was loaded in two parallel lanes $(30 \mu \mathrm{g}$ per lane). After the electrophoresis, one lane was stained with Coomassie blue R-250 and silver. To detect antimicrobial activity, the other lane was overlaid with $10 \mathrm{ml}$ M17 soft agar seeded with $10 \mu \mathrm{l}$ of a fresh overnight culture of L. lactis subsp. lactis $\mathrm{CH} 001$. Plates were incubated at $30^{\circ} \mathrm{C}$ for $20 \mathrm{~h}$. The antimicrobial activity was eluted from these gels as described for helveticin J by Joerger \& Klaenhammer (1986).

(iii) Electroendosmotic preparative electrophoresis (EPE). Recovery of the purified protein from the butanol extract was achieved by EPE (Curioni et al., 1988, 1989) using native polyacrylamide gels as described by Reniero et al. (1992). The stacking $(\mathrm{T}=3 \%)$ and the running gel $(\mathrm{T}=10 \%)$ were $2 \mathrm{~cm}$ and $3 \mathrm{~cm}$ in length, respectively. The fraction-collecting device was set to obtain one fraction every 20 drops $(400 \mu \mathrm{l})$ at a flow rate of $4.8 \mathrm{ml} \mathrm{h}^{-1}$.

SDSPAGE. SDS-PAGE was carried out with a mixture of $15 \%$ $(\mathrm{w} / \mathrm{v})$ acrylamide and $0.4 \%(\mathrm{w} / \mathrm{v})$ bisacrylamide according, to Laemmli (1970). After the electrophoresis, the gels were stained with Coomassie blue R-250 or silver.

Sensitivity to heat and proteolytic enzymes. Crude and purified pediocin A was heated in a boiling water bath. Samples were removed at $0,5,10,30$ and $60 \mathrm{~min}$, and titres were determined to detect activity. To determine the influence of proteolytic enzymes, the following enzymes $\left(1 \mathrm{mg} \mathrm{ml}^{-1}\right)$ were used: trypsin (EC 3.4.21.4) (110 $\left.\mathrm{U} \mathrm{mg}^{-1}\right)$, pronase $\left(7 \mathrm{U} \mathrm{mg}^{-1}\right)$, and proteinase $\mathrm{K}$ (EC 3.4.21.64) $\left(20 \mathrm{U} \mathrm{mg}^{-1}\right)$. Pediocin A/enzyme mixtures were incubated for $30 \mathrm{~min}$ at $37^{\circ} \mathrm{C}$.

Determination of minimal inhibitory concentration (MIC). One-millilitre vials of M17 were inoculated with approximately $10^{3}$ c.f.u. $\mathrm{ml}^{-1}$ of a fresh overnight culture of the indicator strain. Twofold dilutions of purified bacteriocin were added to each vial, ranging from 1.95 to $1000 \mathrm{AU} \mathrm{ml}^{-1}$. The $\mathrm{MIC}$ was defined as the minimal bacteriocin concentration required to inhibit growth after $24 \mathrm{~h}$ incubation.

Antimicrobial spectrum. Bacterial strains and growth conditions for activity spectrum determination of purified pediocin $A$ are listed in Table 2. Strain sensitivity to pediocin A was measured by serial twofold dilutions of purified pediocin A (133.3 AU), as described above (bacteriocin titration). Agar plates were seeded with the strains listed in Table 2 and incubated at the growth temperature of the strain. Strain sensitivities were expressed as a percentage of $L$. lactis subsp. lactis $\mathrm{CH} 001$ sensitivity to $133 \cdot 3 \mathrm{AU}$ of pediocin A.

\section{RESULTS}

\section{Production of pediocin A in M17 medium}

To maximize the recovery of antimicrobial activity, the relationship of culture growth and production was studied during a $24 \mathrm{~h}$ incubation. Titres of activity increased as the growth increased (Fig. 1). There was a linear relation between c.f.u. count and activity that was described by the following linear regression formula:

$$
\begin{aligned}
& y=0.475 x-3.105\left(r^{2}=0.91\right) \\
& \left.\quad\left[x=\log \text { (c.f.u. } \mathrm{ml}^{-1}\right) ; y=\log \left(\mathrm{AU} \mathrm{m}^{-1}\right)\right] .
\end{aligned}
$$

The antimicrobial protein was constitutively expressed, with no relation to the physiological status of the culture; and it appeared to be stable, with no loss of activity after the exponential phase as described for other bacteriocins

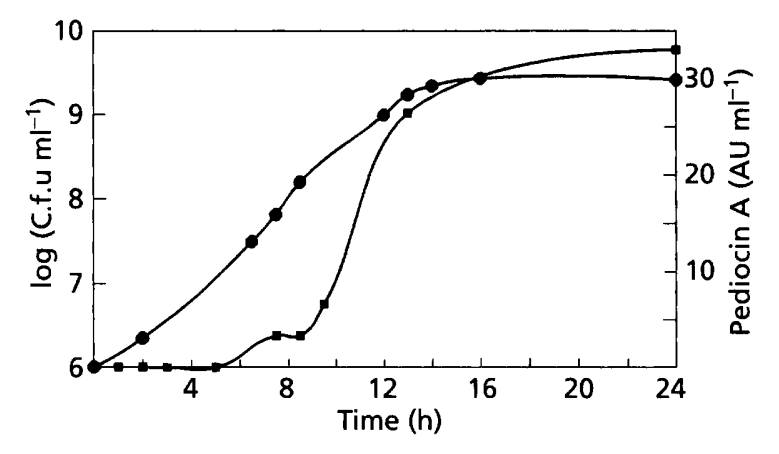

Fig. 1. Producer growth and pediocin A production. Growth (c.f.u. $\mathrm{ml}^{-1}$ ); $\mathbf{\square}$, pediocin A activity. Means of five experiments are plotted.

\begin{tabular}{|c|c|c|c|c|c|c|c|c|}
\hline $\begin{array}{l}\text { Purification } \\
\text { stage }\end{array}$ & $\begin{array}{l}\text { Vol } \\
(\mathrm{ml})\end{array}$ & $\begin{array}{l}\text { Total } \\
\text { activity } \\
\text { (AU) }\end{array}$ & $\begin{array}{c}\text { Pediocin } \mathbf{A} \\
\text { activity } \\
\left(\mathbf{A} \mathbf{U} \mathbf{l}^{-1}\right)\end{array}$ & $\begin{array}{l}\text { Total } \\
\text { protein } \\
(\mathrm{mg})\end{array}$ & $\begin{array}{c}\text { Protein } \\
\text { concn } \\
\left(\mathrm{mg} \mathrm{ml}^{-1}\right)\end{array}$ & $\begin{array}{c}\text { Sp. act. } \\
\left(\mathbf{A U ~} \mathrm{mg}^{-1}\right)\end{array}$ & $\begin{array}{c}\text { Activity } \\
\text { recovered } \\
(\%)\end{array}$ & $\begin{array}{c}\text { Purification } \\
\text { (-fold) }\end{array}$ \\
\hline Culture supernatant & 1000 & 33000 & 33 & 17500 & $17 \cdot 5$ & $1 \cdot 9$ & 100 & 1 \\
\hline Dialysis against $\mathrm{PEG}$ & 100 & 32000 & 320 & 13000 & 130 & $2 \cdot 5$ & 96.9 & $1 \cdot 3$ \\
\hline Butanol extraction & 10 & 5333 & $533 \cdot 3$ & 6 & $0 \cdot 6$ & 889 & $16 \cdot 2$ & 468 \\
\hline EPE & $0 \cdot 4$ & 1280 & 3200 & 0.086 & $0 \cdot 215$ & 14884 & 3.9 & 7834 \\
\hline
\end{tabular}

Table 1. Purification of pediocin A 


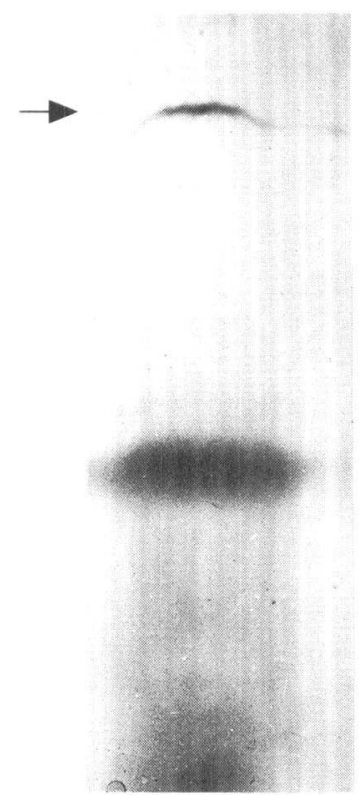

(a)

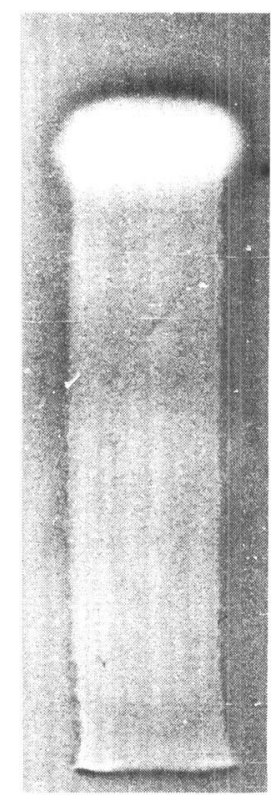

(b)
Fig. 2. Non-denaturing PAGE of butanol extract $(30 \mu \mathrm{g}$ per lane). (a) Silver-stained gel; (b) detection of antimicrobial activity. The arrow indicates the band corresponding to the inhibitory halo. More than 20 non-denaturing PAGEs of butanol extract were run to detect antimicrobial activity, with different electrophoresis conditions. Inhibitory haloes always corresponded to the upper stained band.

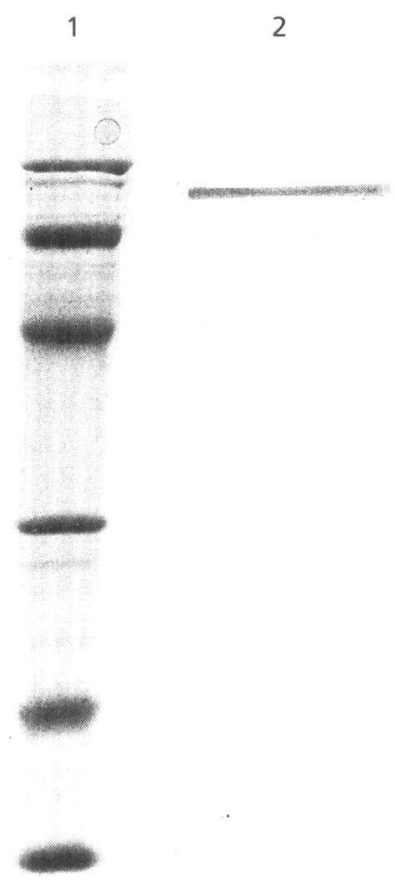

Fig. 3. Coomassie-blue stained SDS-PAGE of pediocin A. Lane 1, molecular mass markers (rabbit muscle phosphorylase $b$, $97.4 \mathrm{kDa}$; bovine serum albumin, $66.2 \mathrm{kDa}$; ovalbumin, $42.7 \mathrm{kDa}$; bovine carbonic anhydrase, $31 \mathrm{kDa}$; soybean trypsin inhibitor, $21.5 \mathrm{kDa}$; lysozyme, $14.4 \mathrm{kDa}$ ). Lane 2 , pediocin $A$ $(10 \mu \mathrm{g})$ eluted from EPE.
(Barefoot \& Klaenhammer, 1984; Joerger \& Klaenhammer, 1986).

\section{Purification of pediocin A}

Crude pediocin A preparation $\left(100 \mathrm{ml}, 3 \cdot 2 \times 10^{4} \mathrm{AU}\right)$ was subjected to butanol extraction. Titration of the butanol and aqueous phases for antimicrobial activity indicated that no activity remained in the aqueous phase, whereas the butanol phase, following freeze-drying, resuspension and dialysis against distilled water, was inhibitory against the indicator strain. This indicated the hydrophobic nature of pediocin A. Unfortunately, even if the extraction was carried out at low temperature, pediocin A activity was reduced to $20 \%$ by this extraction procedure; nevertheless the enrichment was highly significant (Table 1). Organic solvents can act as denaturing agents, causing considerable loss of activity (Wilson \& Goulding, 1986).

Electrophoresis of the butanol extract on non-denaturing polyacrylamide gels resulted in two bands (Fig. 2); direct detection of antimicrobial activity by overlaying the gel with soft agar seeded with the indicator strain revealed that the upper band was active (Fig. 2). This band was eluted and analysed by SDS-PAGE, resulting in a single protein band of approximately $80 \mathrm{kDa}$, providing direct evidence that this band contained pediocin $\mathrm{A}$.

To scale up the recovery of pure pediocin A, nondenaturing gel elution was replaced by nondenaturing EPE. Butanol extract (5333 AU) was applied to a native polyacrylamide column and the elution profile showed two peaks (data not shown) corresponding to the two bands seen on non-denaturing PAGE (Fig. 2). Each eluted fraction was assayed for antimicrobial activity and was analysed by SDS-PAGE. Only the fraction corresponding to the second peak was highly inhibitory to the indicator strain; on SDS-PAGE it showed only a single band, of approximately $80 \mathrm{kDa}$ (Fig. 3). None of the buffers used in these experiments was inhibitory to L. lactis subsp. lactis CH001. Pediocin A was eluted following electrophoresis for $8.5 \mathrm{~h}$. This protocol allowed $3.9 \%$ activity recovery (Table 1 ).

\section{Enzyme and heat inactivation}

Pediocin A activity was completely eliminated upon treatment with trypsin, pronase or proteinase $\mathrm{K}$ (data not shown). After incubation of crude or purified pediocin A at $100{ }^{\circ} \mathrm{C}$ for $5 \mathrm{~min}$ the bacteriocin activity was reduced to $20 \%$, and after $10 \mathrm{~min}$ only $5 \%$ of the original activity remained. No appreciable difference in inactivation was observed between crude and purified pediocin A. These results do not agree with those of Rueckert (1979): every attempt to detect antimicrobial activity from either crude or purified pediocin $\mathrm{A}$ heated at $100{ }^{\circ} \mathrm{C}$ for $60 \mathrm{~min}$ failed, confirming its heat sensitivity.

\section{MIC}

The MIC for L. lactis subsp. lactis $\mathrm{CH} 001$ was $31 \cdot 25 \mathrm{AU}$ $\mathrm{ml}^{-1}$. 
Table 2. Activity spectrum of pediocin A

Sensitivity of strains to pediocin A was measured with serial twofold dilutions of purified bacteriocin (133.3 AU). See Methods for details.

\begin{tabular}{|c|c|c|c|}
\hline Target strain & $\begin{array}{c}\text { Temp. } \\
\left({ }^{\circ} \mathrm{C}\right)\end{array}$ & Medium* & $\begin{array}{l}\text { Pediocin A } \\
\text { sensitivity } \dagger\end{array}$ \\
\hline Lactobacillus acidophilus ATCC 4356 & 37 & MRS & 50 \\
\hline Lactobacillus bulgaricus ATCC 11842 & 42 & MRS & 25 \\
\hline Lactobacillus casei ATCC 334 & 37 & MRS & 5 \\
\hline Lactobacillus curvatus NCFB 2739 & 30 & MRS & 5 \\
\hline Lactobacillus fermentum ATCC 9338 & 37 & MRS & 65 \\
\hline Lactobacillus belveticus ATCC 15009 & 42 & MRS & 100 \\
\hline Lactobacillus plantarum NCDO 1193 & 37 & MRS & 5 \\
\hline Lactobacillus reuteri DMS 20016 & 37 & MRS & 5 \\
\hline Lactobacillus sake NCFB 2714 & 30 & MRS & 88 \\
\hline Lactobacillus salivarius NCFB 2747 & 37 & MRS & 10 \\
\hline Pediococcus pentosaceus FBB 63 & 30 & M17 & 0 \\
\hline Pediococcus pentosaceus PC 1 & 30 & M17 & 38 \\
\hline Propionibacterium acidipropionici NCDO 563 & 30 & M17 & 50 \\
\hline Lactococcus cremoris CNRZ 177 & 25 & M17 & 50 \\
\hline Leuconostoc cremoris DB 1275 & 25 & M17 & 38 \\
\hline Stapbylococcus thermophilus ST 20 & 42 & M17 & 75 \\
\hline Staphylococcus thermophilus ST 112 & 42 & M17 & 75 \\
\hline Staphylococcus carnosus MC 1 & 37 & $\mathrm{BHI}$ & 75 \\
\hline Bacillus cereus ATCC 9139 & 37 & $\mathrm{BHI}$ & 10 \\
\hline Listeria innocua $\mathrm{BL} 86 / 26$ & 30 & $\mathrm{BHI}$ & 10 \\
\hline Enterococcus faecalis EF 1 & 37 & $\mathrm{BHI}$ & 65 \\
\hline Clostridium sporogenes C $22 / 10$ & 37 & $\mathrm{RCM}$ & 65 \\
\hline Clostridium tyrobutyricum 3.5 & 30 & $\mathrm{RCM}$ & 50 \\
\hline Clostridium tyrobutyricum NCDO 1754 & 30 & $\mathrm{RCM}$ & 75 \\
\hline Lactococcus lactis $\mathrm{CH} 001$ & 30 & M17 & 100 \\
\hline Pediococcus pentosaceus FBB61 & 30 & M17 & 0 \\
\hline Pediococcus pentosaceus FBB61-2 $\ddagger$ & 30 & M17 & 100 \\
\hline
\end{tabular}

* MRS medium (De Man et al., 1960) was used without Tween 80. BHI, brain-heart infusion (Difco); RCM, reinforced clostridial medium (Oxoid).

† Mean values of at least three experiments, expressed as a percentage of the sensitivity of the standard test strain L. lactis subsp. lactis $\mathrm{CH} 001$.

¥ Isogenic mutant that does not produce pediocin A (Daeschel \& Klaenhammer, 1985).

\section{Antimicrobial spectrum}

P. pentosaceus FBB61 exhibited antimicrobial activity against almost all Gram-positive micro-organisms tested by the agar-spot method (data not shown). The utilization of serial dilutions of purified pediocin A against each strain tested allowed us to measure their relative sensitivities and to verify the broad spectrum of activity of this bacteriocin (Table 2).

\section{DISCUSSION}

We have confirmed that the antimicrobial agent produced by $P$. pentosaceus FBB61, pediocin A, is a bacteriocin. The sensitivity of pediocin $A$ to heat and proteolytic enzymes demonstrated its proteinaceous nature. $P$. pentosaceus FBB61 and pure pediocin A had an identical broad spectrum of bactericidal activity against almost all Gram- positive strains tested. Purification of pediocin A was achieved by PEG 20000 dialysis, butanol extraction and EPE. The purification resulted in an approximately $7834-$ fold increase in the specific activity of pediocin $A$ and $3.9 \%$ recovery. Electrophoresis experiments showed that a $80 \mathrm{kDa}$ protein could be identified as pediocin A.

Among bacteriocins of the genus Pediococcus that have been purified to date, pediocin $A$ is the largest, at $80 \mathrm{kDa}$. A wide range of different molecular masses was also observed for Lactobacillus bacteriocins (Joerger \& Klaenhammer, 1986; Rammelsberg \& Radler, 1990). The heat sensitivity of pediocin A appeared to be consistent with the size and the apparent complexity of this protein compared with other bacteriocins.

Every attempt to detect the antimicrobial activity directly in SDS-PAGE failed, whereas it was successful for pediocin AcH (Bhunia et al., 1987). However, SDS was 
highly inhibitory to the indicator strain; it is also possible that SDS inactivated pediocin A by altering its native state.

Pediocin A was also purified by ion-exchange and hydrophobic interaction chromatography (HIC) from a semi-synthetic medium prepared as described by Reniero et al. (1993) (data not shown). The hydrophobic nature of pediocin A was evidenced by the butanol extraction and the HIC elution profile. Chromatography of pediocin A on a $\mathrm{C}_{18}$ reversed-phase column revealed that the bacteriocin was eluted with $32 \%$ acetonitrile (data not shown). Hydrophobicity is a common feature of several bacteriocins (Joerger \& Klaenhammer, 1986; Muriana \& Klaenhammer, 1991; Mortvedt et al., 1991; Piard et al., 1992). This suggests that the cell membrane is a possible target, as demonstrated for lactococcin A (van Belkum et al., 1991).

Because of the potential use of bacteriocins of lactic acid bacteria as food preservatives, it is of great importance to gain insight into their chemical structure and their interaction with different food components that may affect their antimicrobial activity. The choice of M17 medium for our experiments was essentially on the basis of the absence of the non-ionic detergent Tween 80 . If $0.01 \%$ Tween 80 was included in this medium, no antimicrobial activity was detectable. As previously reported for lactocin S (Mortvedt et al., 1991), the exclusion of Tween 80 from MRS medium resulted in a high recovery of antimicrobial activity. Common food additives like soybean and egg yolk phosphatidylcholine showed the same effects as Tween 80 in inhibiting the antimicrobial activity of pediocin A (data not shown). Clearly, further studies of pediocin $\mathrm{A}$ are required to elucidate its possible role as a food preservative.

\section{ACKNOWLEDGEMENTS}

We gratefully acknowledge Dr M. C. Callegari, Dr R. Reniero and Dr D. McDonagh for their efficient help.

\section{REFERENCES}

Barefoot, S. F. \& Klaenhammer, T. R. (1984). Purification and characterization of the Lactobacillus acidophilus bacteriocin lactacin B. Antimicrob Agents Chemother 26, 328-334.

van Belkum, M. J., Kok, J., Venema, G., Holo, H., Nes, I. F., Konings, W. N. \& Abee, T. (1991). The bacteriocin lactococcin A specitically increases permeability of lactococcal cytoplasmic membranes in a voltage-independent, protein-mediated manner. J Bacteriol 173, 7934-7941.

Bhunia, A. K., Johnson, M. C. \& Ray, B. (1987). Direct detection of an antimicrobial peptide of Pediococcus acidilactici in sodium dodecyl sulfate-polyacrylamide gel electrophoresis. I Ind Microbiol 2, 319-322.

Bhunia, A. K., Johnson, M. C. \& Ray, B. (1988). Purification, characterization and antimicrobial spectrum of a bacteriocin produced by Pediococcus acidilactici. J Appl Bacteriol 65, 261-268.

Costilow, R. N., Coughlin, F. M., Robach, D. L. \& Ragheb, H. S. (1956). A study of the acid-forming bacteria from cucumber fermentations in Michigan. Food Res 21, 27-33.
Curioni, A., dal Belin Peruffo, A. \& Nuti, M. P. (1988). Purification of cellulases from Streptomyces strain A20 by electroendosmotic preparative electrophoresis. Electrophoresis 9, 327-330.

Curioni, A., dal Belin Peruffo, A. \& Pogna, N. E. (1989). Electroendosmotic preparative electrophoresis as a one-step method for purification of high molecular weight subunits of wheat glutenin. Cereal Chem 66, 133-135.

Daeschel, M. A. \& Klaenhammer, T. R. (1985). Association of a 13.6-megadalton plasmid in Pediococcus pentosaceus with bacteriocin activity. Appl Environ Microbiol 50, 1538-1541.

De Man, J. C., Rogosa, M. \& Sharpe, M. E. (1960). A medium for the cultivation of lactobacilli. J Appl Bacteriol 23, 130-135.

Etchells, J. L., Costilow, R. N., Anderson, T. E. \& Bell, T. A. (1964). Pure culture fermentation of brined cucumbers. Appl Microbiol 12, 523-535.

Food and Drug Administration (1988). Nisin preparation: affirmation of GRAS status as a direct human food ingredient. Fed Reg April 6, 1988, 53, 11247-11250.

Fleming, H. P., Etchells, J. L. \& Costilow, R. N. (1975). Microbial inhibition by an isolate of Pedicococcus from cucumber brines. Appl Microbiol 30, 1040-1042.

Henderson, J. T., Chopko, A. L. \& van Wassenaar, P. D. (1992). Purification and primary structure of pediocin PA-1 produced by Pediococcus pentosaceus PAC 1.0. Arch Biochem Biophys 295, 5-12.

Joerger, M. C. \& Klaenhammer, T. R. (1986). Characterization and purification of helveticin $\mathrm{J}$ and evidence for a chromosomally determined bacteriocin produced by Lactobacillus belveticus 481 . $J$ Bacteriol 167, 439-446.

Laemmli, U. K. (1970). Cleavage of structural proteins during the assembly of the head of bacteriophage T4. Nature 227, 680-685.

Motlagh, A. M., Bhunia, A. K., Szostek, F., Hansen, T. R., Johnson, M. C. \& Ray, B. (1992). Nucleotide and aminoacid sequence of PAPgene pediocin $\mathrm{AcH}$ production in Pediococcus acidilactici $\mathrm{H}$. Lett Appl Microbiol 15 (2), 45-48.

Mortvedt, C. I., Nissen-Meyer, J., Sletten, K. \& Nes, I. F. (1991). Purification and aminoacid sequence of lactocin $\mathrm{S}$, a bacteriocin produced by Lactobacillus sake L45. Appl Environ Microbiol 57, 1829-1834.

Muriana, P. M. \& Klaenhammer, T. R. (1991). Purification and partial characterization of lactacin $\mathrm{F}$, a bacteriocin produced by Lactobacillus acidopbilus 11088. Appl Environ Microbiol 57, 114-121.

Piard, J. C., Muriana, P. M., Desmazeaud, M. J. \& Klaenhammer, T. R. (1992). Purification and partial characterization of lacticin 481, a lanthionine-containing bacteriocin produced by Lactococcus lactis subs. lactis CNRZ 481. Appl Environ Microbiol 58, 279-284.

Pucci, M. J., Vedamuthu, E. R., Kunka, B. S. \& Vandenbergh, P. A. (1988). Inhibition of Listeria monocytogenes by using bacteriocin PA1 produced by Pediococcus acidilactici PAC 1.0. Appl Environ Microbiol 54, 2349-2353.

Rammelsberg, M. \& Radler, F. (1990). Antibacterial polypeptides of Lactobacillus species. J Appl Bacteriol 69, 177-184.

Reniero, R., Cocconcelli, P. S., Bottazzi, V. \& Morelli, L. (1992). High frequency of conjugation in Lactobacillus mediated by an aggregation-promoting factor. J Gen Microbiol 138, 763-768.

Reniero, R., Piva, A., Morelli, L., Bottazzi, V. \& Cocconcelli, P. S. (1993). Purification of Lactobacillus secreted proteins. Biotechnol Tech 7, 401-406.

Rueckert, P. W. (1979). Studies on a bacteriocin-like activity produced by Pediococcus pentosaceus effective against gram-positive organisms. MS thesis, Michigan State University, East Lansing.

Sambrook, J., Fritsch, E. F. \& Maniatis, T. (1989). Molecular Cloning. 
a Laboratory Manual, 2nd edn. Cold Spring Harbor, NY: Cold Spring Harbor Laboratory.

Spelhaug, S. R. \& Harlander, S. K. (1989). Inhibition of foodborne bacterial pathogens by bacteriocins from Lactococcus lactis and Pediococcus pentosaceus. J Food Prot 52, 856-862.

Wilson, K. \& Goulding, K. H. (1986). Purificazione degli enzimi. In Biochimica Applicata, pp. 90-93. Edited by M. Pilone Simonetta \& G. Hanozet. Milan: R. Cortina.
Yousef, A. E., Luchansky, J. B., Degnan, A. J. \& Doyle, M. P. (1991). Behavior of Listeria monocytogenes in weiner exudates in the presence of Pediococcus acidilactici $\mathrm{H}$ or pediocin $\mathrm{AcH}$ during storage at 4 or $25^{\circ} \mathrm{C}$. Appl Environ Microbiol 57, 1461-1467.

Received 3 September 1993; revised 14 October 1993; accepted 22 October 1993. 